\title{
Implementation and progress of an inclusive primary health care model in Guatemala: coverage, quality, and utilization
}

\author{
Meredith P. Fort, ${ }^{1}$ David E. Grembowski, ${ }^{1}$ Juan C. Verdugo, ${ }^{2}$ Lidia C. Morales, ${ }^{2}$ \\ Carmen A. Arriaga, ${ }^{2}$ Mary A. Mercer, ${ }^{3}$ and Stephen S. Lim ${ }^{4}$
}

Suggested citation Fort MP, Grembowski DE, Verdugo JC, Morales LC, Arriaga CA, Mercer MA, Lim SS. Implementation and progress of an inclusive primary health care model in Guatemala: coverage, quality, and utilization. Rev Panam Salud Publica. 2011;30(3):217-24.

ABSTRACT Objective. To describe a primary health care model designed specifically for Guatemala that has been implemented in two demonstration sites since 2004 and present results of a process evaluation of utilization, service coverage, and quality of care from 2005 to 2009.

Methods. Coverage, utilization, and quality were assessed by using an automated database linking census and clinical records and were reported over time. Key maternal and child health coverage measures were compared with national-level measures.

Results. The postnatal coverage achieved by the Modelo Incluyente de Salud of nearly $100.0 \%$ at both sites contrasts with the national average of $25.6 \%$. Vaccination coverage for children aged 12-23 months in the Modelo Incluyente de Salud reached 95.6\% at site 1 (Bocacosta, Sololá) and $92.7 \%$ at site 2 (San Juan Ostuncalco), compared with the national average of $71.2 \%$. Adherence to national treatment guidelines increased significantly at both sites with a marked increase between 2006 and 2007. Utilization increased significantly at both sites, with only $7.5 \%$ of families at site 1 and $11.2 \%$ of families at site 2 not using services by the end of the 5-year period.

Conclusions. Coverage, quality of care, and utilization measures increased significantly during the 5-year period when the service delivery model was implemented. This finding suggests a strong possibility that the model may have a benefit for health outcomes as well as for process measures. The Modelo Incluyente de Salud will be financially sustained by the Ministry of Health and extended to at least three additional sites. The model provides important lessons for primary care programs internationally.

Key words Primary health care; program evaluation; health services evaluation; Guatemala.

Effective primary health care models that track data at an individual level and

\footnotetext{
1 University of Washington, Health Services, Seattle, Washington 98195, United States of America. Send correspondence to: Meredith P. Fort, mpfort@uw.edu

2 Instituto de Salud Incluyente, San Lucas, Sacatepequez, Guatemala.

3 University of Washington, Health Services and Global Health, Seattle, Washington, United States of America.

4 University of Washington, Global Health, Institute of Health Metrics and Evaluation, Seattle, Washington, United States of America.
}

aim to reach underserved groups are a priority for the global health community and are considered a means to increase service coverage and improve health outcomes $(1,2)$. There are few examples of comprehensive primary health care models in the region that have been implemented over a significant time period and that have data that were rigorously recorded, analyzed, and disseminated. At a national level, Cuba, Costa Rica, and Brazil present some of the most long- term experiences; other, more localized experiences also have important lessons (3-8). It is important to share lessons learned from implementation experiences to build on the knowledge base at national, regional, and global levels.

Despite being a country that has achieved relatively strong economic indicators, Guatemala has lagged behind other countries in the region in terms of health indicators and service delivery measures. With an estimated $49.8 \%$ of 
children considered to be chronically malnourished, Guatemala has the highest rate in Central America (9). While the most recent National Maternal and Child Health Survey reports important reductions in infant mortality-from 39 to 30 per 1000 live births between 2002 and 2008-2009-that rate remains one of the highest in the region. Historically, the Mayan population has experienced social exclusion and continues to have worse health indicators and service coverage measures than the ladino population; $65.9 \%$ of Mayan children are chronically malnourished compared with $36.2 \%$ of ladino children. Similarly, $70.1 \%$ of ladino women's births are attended by medical personnel compared with only 29.5\% of Mayan women's births (9).

Since the Peace Accords in 1996, when an estimated $46.0 \%$ of the populationmostly rural-were found to be without formal health care services (10), the Guatemalan government has focused on expanding care to populations with low levels of coverage, especially in rural areas. Despite these efforts, the health system remains fragmented, with a human resources gap (11).

Starting in 2004, local-level community partner organizations and three Ministry of Health districts began implementing a primary health care model that aims to increase service coverage in an inclusive way. The Modelo Incluyente de Salud has been implemented at two rural sites serving about 20000 people. It presents a learning experience for the Guatemalan population and for the broader, public health community.

\section{DESCRIPTION OF MODELO INCLUYENTE DE SALUD}

For decades, the standard of primary care in rural Guatemala has been a network of Ministry of Health posts and health centers that offer basic primary care services. Health posts are located in remote areas and are generally staffed by one or two auxiliary nurses who serve populations of 1500 to 3000 people. They refer patients who need higherlevel care to well-equipped Ministry of Health centers and hospitals. In 1997, the Ministry of Health initiated Extensión de Cobertura, an ambulatory model of service delivery at the primary care level to extend services to underserved areas. These two service delivery models are ongoing in the country.
In 1998, a coalition of grassroots organizations called the Instancia Nacional de Salud began work developing a primary health care model designed specifically for the Guatemalan context (12). It attempts to explicitly incorporate intercultural and gender equality in a society that has systematically excluded Mayans, rural peasants, and women from social development. It also aims to improve suboptimal service delivery indicators.

The Modelo Incluyente de Salud has been implemented since 2004 at two sites in rural Guatemala: the municipalities of Santa Catarina Ixtahuacán and Nahualá of Bocacosta, Sololá, and San Juan Ostuncalco, Quetzaltenango. Ministry of Health area staff selected the sites because their populations were not receiving services through the Extensión de Cobertura service delivery model and were considered underserved. Both sites are characterized by communities that are rural, are of Mayan ethnicity, are economically dedicated to subsistence and cash crop agriculture, and have high levels of poverty $(90.0 \%$ in Ixtahuacán and $72.5 \%$ in San Juan Ostuncalco). The primary causes of death for children 5 years of age or younger are pneumonia and other treatable acute illnesses $(13,14)$. In Bocacosta, Sololá, the model was implemented in coordination with an organization with more than 40 years of community health experience. In San Juan Ostuncalco, the organization responsible for implementing the model had not worked with the communities in the catchment area before 2005.

The Modelo Incluyente de Salud differs from the government's standard of care in a number of key ways. The model's approach to service delivery is in line with the position paper of the Pan American Health Organization entitled Renewing primary health care in the Americas (2); services are offered through three integrated individual, family, and community programs.

The primary care providers in the Modelo Incluyente de Salud are called agentes de salud comunitaria and have training similar to community auxiliary nurses. They are recognized officially by the Ministry of Health as having training equal to those trained in the national school of nursing. For the remainder of this article they are referred to as community auxiliary nurses. They underwent 6 months of intensive, full-time training in preventive and curative clini- cal care, community and family outreach, and sociocultural explanations of health and disease. They work in teams of two to four and are based at a community health clinic; San Juan Ostuncalco, Quetzaltenango, has four clinics that serve nearly 9000 people and Bocacosta, Sololá, has six clinics for a population of more than 10000 people. Each site has a supervision and referral team that includes a team coordinator trained in public health, a physician, a professional nurse, and one community and one family program facilitator. The physician and nurse supervise clinical care and see complicated cases, the community program facilitator supports community organizing and outreach, and the family program facilitator oversees family visits and sees referred psychosocial cases. Each site has 14 community auxiliary nurses who are from the communities where they work or communities nearby and are bilingual in Spanish and the local Mayan language.

The Modelo Incluyente de Salud explicitly makes an effort to provide care to the entire population in its catchment area. In addition to having community clinics open for service utilization on demand, the Modelo Incluyente de Salud uses a proactive approach to health care. Proactive, continuous, anticipatory health care for an entire population rather than reactive, patient-initiated care improves health outcomes at the population level $(15,16)$. In the Americas, proactive home visits are important strategies used in the health care systems in Brazil (17), Costa Rica (18), and Cuba (19). The proactive components of the Modelo Incluyente de Salud are: the family program (which consists of routine visits to all households to screen for risks), postnatal and newborn home visits, prenatal screening for women who do not seek clinical care, home visits to follow up on high-risk acute illnesses, and active searching for individuals with incomplete vaccination schedules and who have not received iron and folic acid supplements, vitamin A, and antiparasitic drugs.

An additional feature of the Modelo Incluyente de Salud that makes this analysis possible is the investment in routine data collection through an automated database. Individuals and family members are assigned codes, which allow for tracking preventive and curative services. During clinical encounters and family visits, community auxiliary nurses fill out charts 
that are then entered daily into each of the two sites' databases and filed locally at the clinic for reference.

The conceptual model for evaluation of the Modelo Incluyente de Salud is presented in Figure 1 and is based largely on Ronald Andersen's behavioral model, which divides determinants of service utilization into predisposing, enabling, and need factors. The model has been adapted over the past 40 years and continues to be one of the most influential models in health services research (20).

As shown in Figure 1, the Modelo Incluyente de Salud is expected to have improved quality of care, utilization, and coverage results through its staffing structure, its proactive assessment of risks and referral, and its attempt to reach the entire population in the designated catchment area. The process evaluation presented here assesses the extent to which these service delivery measures improve over time and compares them with those achieved nationally. In a future analysis, the influence of individual and family-level social and cultural characteristics (presented on the left side of the conceptual model) on service delivery will be assessed. Similarly, the box that shows health outcomes will be assessed in a future impact evaluation.

The aim of this article is to describe the Modelo Incluyente de Salud and present results of a process evaluation of utilization, service coverage, and quality of care from 2005 to 2009. The objectives of this process evaluation are to measure the change in service coverage, quality of care, and utilization during the implementation period. In addition, when

\section{FIGURE 1. Conceptual model for evaluation of Modelo Incluyente de Salud (MIS)}

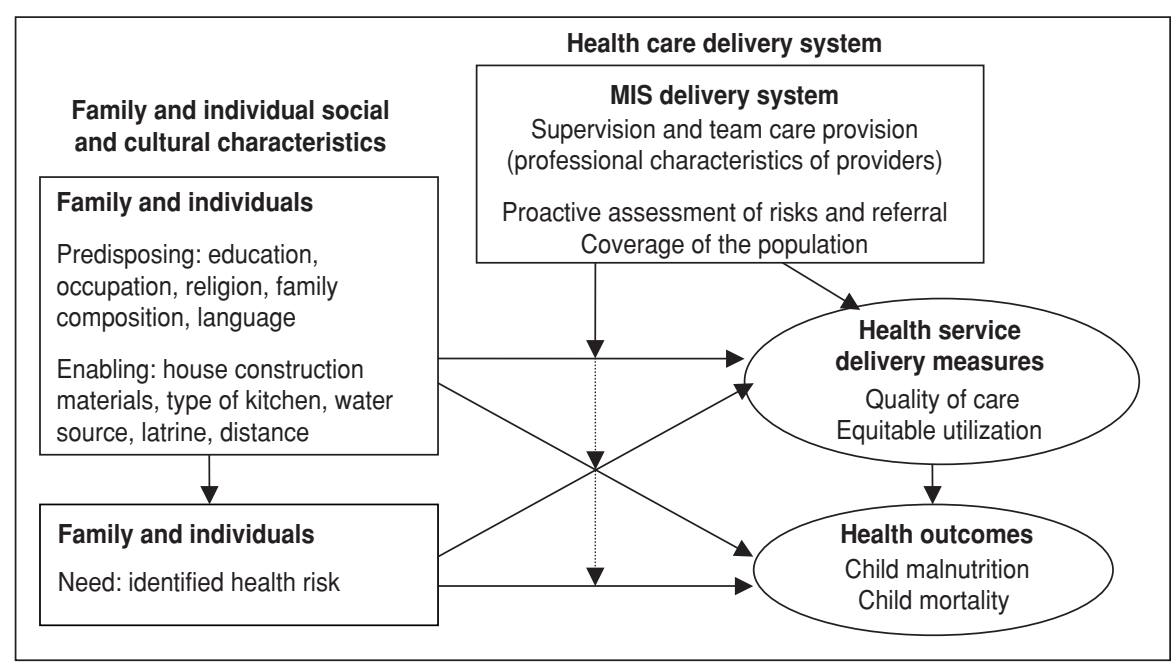

possible, process evaluation results are compared with national-level results. The final objective is to discuss the potential for this model's expansion.

\section{MATERIALS AND METHODS}

\section{Population and study design}

A repeated cross-sectional design was used to assess the changes in utilization, quality, and coverage from the first complete year of implementation (2005) to 2009. The population consisted of all families and individuals at the two sites where the Modelo Incluyente de Salud was implemented.

\section{Data sources and measures}

The data source for the analysis was the Modelo Incluyente de Salud database. The database had census information for all individuals living in the catchment area linked to clinical files, familyscreening visit data, and preventive services including vaccinations and supplementation as defined by Ministry of Health guidelines. Health workers collected census data in 2004 before initiating clinical service delivery. Approximately $10.0 \%$ of families declined to share census data with the project at the outset but then agreed once service delivery began. The census data were updated with birth and death records each month and with an annual update of the number of members in each household. The health care service delivery database, designed after the census was completed, links directly to population-level data through individual and family codes. Service coverage was defined as use of a preventive service for specific subpopulations. The following coverage measures were used: complete vaccination schedules for children aged 1 year, three doses of tetanus for women aged 15-49 years, pregnant women with at least one prenatal check-up, pregnant women with at least three prenatal check-ups, postpartum women with at least one check-up, and newborns with at least one check-up. Health care attendance at birth was not included as it is not a provided service.

Quality was defined as the community auxiliary nurses' adherence to national clinical guidelines in their treatment of children with pneumonia and bacterial tonsillitis. According to national treatment guidelines, the medication indicated for these diseases is amoxicillin. Use of any antibiotic is also assessed. Quality was captured in two indicators of clinical encounters for postpartum women and newborns: how quickly after delivery a postnatal visit was made and whether weight was checked for newborns. Professional turnover was assessed for community auxiliary nurses and the support and supervision team.

Utilization was defined as the number of clinic visits provided by the Modelo Incluyente de Salud to individuals living in the catchment area. Clinical encounters are those made on demand to receive a preventive or curative service at the community clinic. The summary measure for family utilization is the total number of clinic visits made per year by all family members divided by the number of family members.

Costs of the service delivery model at the two sites were computed in US dollars from 2007 data using program records and the standard cost method and are presented to contextualize the results of coverage, utilization, and quality of care. The exchange rate for US dollars to quetzales for 2007 was 7.67 quetzales to $\$ 1$ (21).

\section{Data analysis}

A test of significance between characteristics of the two site populations was conducted using $\chi^{2}$ analysis for categorical variables, $t$-test for continuous variables, and a proportion test for differences in percentages. Annual percentages and summary measures of family utiliza- 
tion of services, vaccination and maternal and child health service coverage, and quality of care were calculated. A $\chi^{2}$ test for trend was performed to determine the significance of percentage increases in utilization, vaccination coverage, and quality-of-care measures over the 5-year The significance level for all tests was set at $P=0.05$.

\section{RESULTS}

Table 1 presents the baseline sociodemographic characteristics for the two communities where the Modelo Incluyente de Salud is being implemented. The size of families and the average age of the head of household are significantly different for the two sites at the $P<0.05$ level, but the differences between the two period of the model's implementation.

communities for these characteristics are not substantial.

Both communities are characterized as having lower than average levels of social development compared with the national level. Agriculture is the primary labor activity for $76.4 \%$ of heads of households in Bocacosta and for $81.0 \%$ of families in San Juan Ostuncalco, compared with $33.2 \%$ nationally; $83.1 \%$ of families in Bocacosta and $63.2 \%$ in San Juan Ostuncalco have dirt floors compared with $30.9 \%$ of families nationally (22).

Neither site is consistently higher or lower than the other for the characteristics of interest. In both communities, more than half of heads of household have no primary school education. The populations at both sites are considered to be Mayan but are notably different

TABLE 1. Selected sociodemographic characteristics at baseline for Bocacosta, Sololá, and San Juan Ostuncalco, 2006

\begin{tabular}{|c|c|c|c|}
\hline Characteristic & $\begin{array}{l}\text { Bocacosta, } \\
\text { Sololá } \\
\text { (site 1) }\end{array}$ & $\begin{array}{l}\text { San Juan } \\
\text { Ostuncalco } \\
\text { (site 2) }\end{array}$ & $\begin{array}{l}\text { Difference } \\
(P \text {-value })\end{array}$ \\
\hline Total number of families & 1723 & 1279 & \\
\hline Mean number of family members (SD) & $6.2(2.9)$ & $7.2(3.3)$ & $P<0.001$ \\
\hline \multicolumn{4}{|l|}{ Head-of-household characteristic } \\
\hline Average age of head of household (SD) & $42.2(14.6)$ & $41.6(14.5)$ & $P=0.03$ \\
\hline Highest level of education achieved & & & $\chi^{2} P<0.001$ \\
\hline Number with no primary education (\%) & $899(53.0)$ & $772(63.0)$ & \\
\hline Primary labor activity & & & $\chi^{2} P<0.001$ \\
\hline $\begin{array}{l}\text { Number practicing subsistence and } \\
\text { commercial agriculture (\%) }\end{array}$ & $1211(76.4)$ & $867(81.0)$ & \\
\hline Language spoken & & & $\chi^{2} P<0.001$ \\
\hline Number speaking only Mayan language (\%) & $921(54.5)$ & $157(12.8)$ & \\
\hline Number speaking Mayan language and Spanish (\%) & $768(45.5)$ & $1069(87.2)$ & \\
\hline Number of households with dirt floor (\%) & $1143(83.1)$ & $712(63.2)$ & $\chi^{2} P<0.001$ \\
\hline
\end{tabular}

Note: SD: standard deviation. Percentages are calculated for all households with data; because of missing data for some variables, percentages may not be based on the total number of households. with respect to their ability to speak Spanish. In Bocacosta, Sololá, most heads of household are monolingual in the Mayan language $\mathrm{K}^{\prime}$ iche, whereas in San Juan Ostuncalco, $87.2 \%$ speak both Spanish and the Mayan language Mam.

The most substantial change demonstrated by the Modelo Incluyente de Salud is the increased coverage for key priority maternal and child health services, which are presented in Table 2. Complete vaccination coverage for children 12-23 months (one bacillus CalmetteGuérin, one measles/mumps/rubella, and three diphtheria/pertussis/tetanus + influenza type $\mathrm{b}+$ hepatitis $\mathrm{B}$, and three polio doses) increased at site 1 (Bocacosta, Sololá) from $48.1 \%$ in 2005 to $96.1 \%$ in 2009 and at site 2 (San Juan Ostuncalco) from $44.8 \%$ to $92.7 \%$ for the same years. The percentage of women aged 15-49 with three tetanus vaccines increased at site 1 from $13.7 \%$ in 2005 to $62.0 \%$ in 2009 and at site 2 from $7.9 \%$ to $54.7 \%$. The test for trend of vaccination coverage was significant $(P<0.0001)$ at both sites.

As reported in Table 3, coverage of prenatal, postnatal, and newborn visits increased substantially between 2006 and 2009 at both sites. By 2009, more than $90.0 \%$ of pregnant women at both sites received at least one prenatal care visit and $71.9 \%$ at site 1 and $62.5 \%$ at site 2 received the recommended three prenatal care visits during pregnancy.

The Modelo Incluyente de Salud prioritizes follow-up with mothers and children after delivery. Postpartum visits were close to $100.0 \%$ at both sites by 2009, and newborn screenings reached

TABLE 2. Vaccination coverage rates for children 1 year of age and women 15-49 years of age at Bocacosta, Sololá, and San Juan Ostuncalco, 2005-2009

\begin{tabular}{|c|c|c|c|c|c|}
\hline & 2005 & 2006 & 2007 & 2008 & 2009 \\
\hline \multicolumn{6}{|l|}{ Bocacosta, Sololá (site 1) } \\
\hline Number of children 1 year of age & 285 & 331 & 295 & 306 & 283 \\
\hline Number of children 1 year of age & & & & & \\
\hline with complete schedules (\%) & $137(48.1)$ & $212(64.1)$ & $225(76.3)$ & $279(91.2)$ & $272(96.1)$ \\
\hline Number of women aged $15-49$ years & 1945 & 2381 & 2527 & 2592 & 2734 \\
\hline $\begin{array}{l}\text { Number of women aged } 15-49 \text { years } \\
\text { with three tetanus shots } \% \text { ) }\end{array}$ & & & & & \\
\hline \multicolumn{6}{|l|}{ San Juan Ostuncalco (site 2) } \\
\hline Number of children 1 year of age & 259 & 223 & 235 & 225 & 248 \\
\hline with complete schedules (\%) & $116(44.8)$ & $169(75.8)$ & $176(74.9)$ & $207(92.0)$ & 230 (92.7) \\
\hline Number of women aged $15-49$ years & 1793 & 1962 & 2062 & 2121 & 2257 \\
\hline $\begin{array}{l}\text { Number of women aged } 15-49 \text { years } \\
\text { with three tetanus shots (\%) }\end{array}$ & $142(7.9)$ & $324(16.5)$ & $548(26.6)$ & 777 (41.4) & $1235(54.7)$ \\
\hline
\end{tabular}


TABLE 3. Coverage of prenatal, postnatal, and newborn check-ups for Bocacosta, Sololá, and San Juan Ostuncalco, 2006 and 2009

\begin{tabular}{|c|c|c|c|c|}
\hline & \multicolumn{2}{|c|}{ Site 1: Bocacosta, Sololá } & \multicolumn{2}{|c|}{ Site 2: San Juan Ostuncalco } \\
\hline & 2006 & 2009 & 2006 & 2009 \\
\hline Live births & 305 & 250 & 232 & 255 \\
\hline Stillbirths & 8 & 6 & 5 & 6 \\
\hline Total births & 313 & 256 & 237 & 261 \\
\hline $\begin{array}{l}\text { Number of pregnant women with at least } \\
\text { one prenatal care visit (\%) }\end{array}$ & $202(64.5)$ & $252(98.4)$ & $96(40.5)$ & 245 (93.9) \\
\hline $\begin{array}{l}\text { Number of pregnant women with at least } \\
\text { three prenatal care visits (\%) }\end{array}$ & $85(27.2)$ & $184(71.9)$ & $38(16.0)$ & $163(62.5)$ \\
\hline $\begin{array}{l}\text { Number of women with at least one } \\
\text { postpartum visit (\%) }\end{array}$ & $278(88.8)$ & $269(105.1)^{\mathrm{a}}$ & $128(54.0)$ & $256(98.1)$ \\
\hline $\begin{array}{l}\text { Mean number of days for postpartum visit } \\
\text { after delivery (SD) }\end{array}$ & $5.0(6.6)$ & $3.3(4.0)$ & $13.3(8.6)$ & $4.1(4.3)$ \\
\hline $\begin{array}{l}\text { Number of women with immediate postpartum } \\
\text { visit (first } 24 \text { hours) (\%) }\end{array}$ & 28.8 & 31.9 & 4.7 & 32.0 \\
\hline $\begin{array}{l}\text { Number of women with mediate postpartum } \\
\text { visit ( } 25 \text { hours to } 7 \text { days) (\%) }\end{array}$ & 52.9 & 61.0 & 24.2 & 53.9 \\
\hline $\begin{array}{l}\text { Number of women with late postpartum visit } \\
(8-42 \text { days })(\%)\end{array}$ & 18.3 & 7.1 & 71.1 & 14.1 \\
\hline Total newborn visits & 205 & 239 & 115 & 236 \\
\hline $\begin{array}{l}\text { Number of newborn visits with weight } \\
\text { check (\%) }\end{array}$ & $121(59.0)$ & 209 (87.5) & $101(87.8)$ & $233(98.7)$ \\
\hline
\end{tabular}

Note: SD: standard deviation.

a Postnatal control coverage was greater than $100 \%$ in 2009 because it captured women whose pregnancies did not come to full term but who received a follow-up visit classified as postnatal.
$95.6 \%$ at site 1 and $92.5 \%$ at site 2 . On average, site 1 postpartum visits were made 5 days after delivery in 2006 and 3 days after delivery in 2009. Site 2 postpartum visits were made on average 13 days after delivery in 2006, and by 2009 they were made 4 days after delivery. At both sites, by 2009 almost one-third of postnatal visits were made within the first 24 hours after delivery. By 2009, $87.5 \%$ of newborn visits at site 1 and $98.7 \%$ at site 2 included a weight check.

Tables 4-6 present data on community auxiliary nurses' adherence to national treatment guidelines for childhood pneumonia and bacterial tonsillitis at the two sites from 2005 to 2009. In 2005, at both sites amoxicillin was prescribed for fewer than half the children with pneumonia, and other antibiotics were prescribed most of the time. Between 2006 and 2007, both sites showed an important increase in following national treatment guidelines for children diagnosed with pneumonia in the 1- to 4-year and

TABLE 4. Prescription for clinical encounters with children aged 1-4 years diagnosed with pneumonia, Bocacosta, Sololá, and San Juan Ostuncalco, 2005-2009

\begin{tabular}{|c|c|c|c|c|c|c|c|c|c|c|c|c|}
\hline \multirow[b]{2}{*}{ Prescription } & \multicolumn{2}{|c|}{2005} & \multicolumn{2}{|c|}{2006} & \multicolumn{2}{|c|}{2007} & \multicolumn{2}{|c|}{2008} & \multicolumn{2}{|c|}{2009} & \multicolumn{2}{|c|}{ All years } \\
\hline & No. & $\%$ & No. & $\%$ & No. & $\%$ & No. & $\%$ & No. & $\%$ & No. & $\%$ \\
\hline \multicolumn{13}{|l|}{ Bocacosta, Sololá (site 1) } \\
\hline Other antibiotic prescribed & 295 & 71.3 & 352 & 72.9 & 40 & 14.0 & 12 & 5.6 & 23 & 6.7 & 722 & 41.5 \\
\hline No antibiotic prescribed & 3 & 0.7 & 3 & 0.6 & 0 & 0.0 & 0 & 0.0 & 2 & 0.6 & 8 & 0.5 \\
\hline Total & 414 & & 483 & & 286 & & 215 & & 343 & & 1741 & \\
\hline \multicolumn{13}{|l|}{ San Juan Ostuncalco (site 2) } \\
\hline No antibiotic prescribed & 7 & 3.1 & 5 & 2.7 & 1 & 0.6 & 1 & 0.8 & 0 & 0.0 & 14 & 1.8 \\
\hline Total & 229 & & 187 & & 165 & & 131 & & 90 & & 802 & \\
\hline
\end{tabular}

Note: The test for trend for quality-of-care measures for antibiotic prescription for children with pneumonia resulted in $P<0.0001$ at both sites.

TABLE 5. Prescription for cinical encounters with children aged 2-12 months diagnosed with pneumonia, Bocacosta, Sololá, and San Juan Ostuncalco, 2005-2009

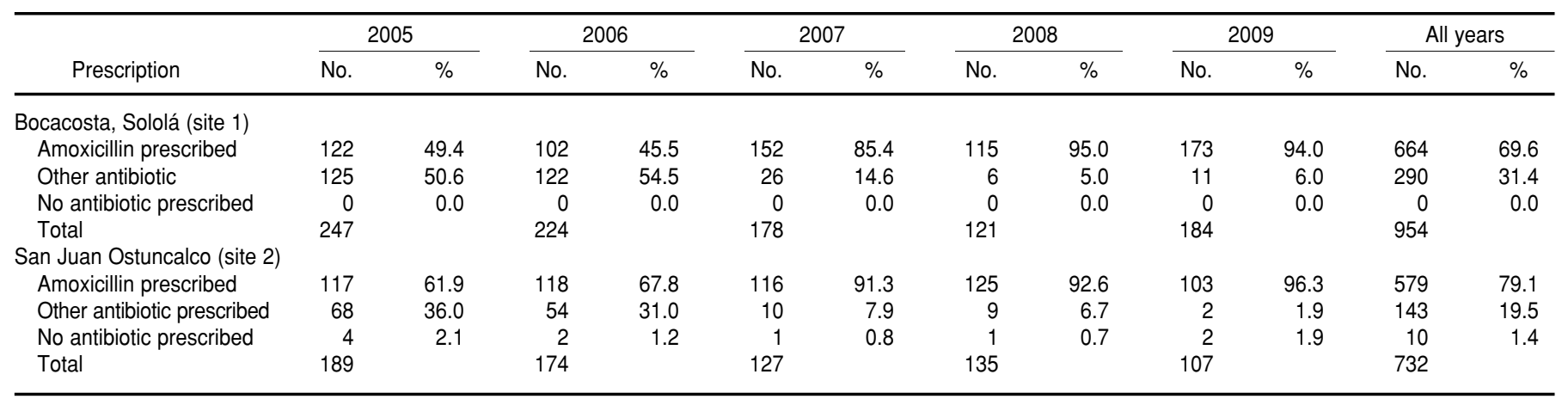

Note: The test for trend for quality-of-care measures for antibiotic prescription for children with pneumonia resulted in $P<0.0001$ at both sites. 
TABLE 6. Prescription for clinical encounters with children aged 1-4 years diagnosed with tonsillitis, Bocacosta, Sololá, and San Juan Ostuncalco, 2005-2009

\begin{tabular}{|c|c|c|c|c|c|c|c|c|c|c|c|c|}
\hline \multirow[b]{2}{*}{ Prescription } & \multicolumn{2}{|c|}{2005} & \multicolumn{2}{|c|}{2006} & \multicolumn{2}{|c|}{2007} & \multicolumn{2}{|c|}{2008} & \multicolumn{2}{|c|}{2009} & \multicolumn{2}{|c|}{ All years } \\
\hline & No. & $\%$ & No. & $\%$ & No. & $\%$ & No. & $\%$ & No. & $\%$ & No. & $\%$ \\
\hline \multicolumn{13}{|l|}{ Bocacosta, Sololá (site 1) } \\
\hline Amoxicillin prescribed & 22 & 55.0 & 45 & 84.9 & 73 & 93.6 & 124 & 96.9 & 259 & 96.6 & 523 & 92.2 \\
\hline Other antibiotic prescribed & 18 & 45.0 & 7 & 13.2 & 5 & 6.4 & 4 & 3.1 & 6 & 2.2 & 40 & 7.1 \\
\hline No antibiotic prescribed & 0 & 0.0 & 1 & 1.9 & 0 & 0.0 & 0 & 0.0 & 3 & 1.1 & 4 & 0.7 \\
\hline Total & 40 & & 53 & & 78 & & 128 & & 268 & & 567 & \\
\hline \multicolumn{13}{|l|}{ San Juan Ostuncalco (site 2) } \\
\hline Amoxicillin prescribed & 27 & 84.4 & 75 & 87.2 & 123 & 93.9 & 188 & 95.9 & 274 & 97.2 & 687 & 94.5 \\
\hline Other antibiotic prescribed & 5 & 15.6 & 10 & 11.6 & 6 & 4.6 & 8 & 4.1 & 4 & 1.4 & 33 & 4.5 \\
\hline No antibiotic prescribed & 0 & 0.0 & 1 & 1.2 & 2 & 1.5 & 0 & 0.0 & 4 & 1.4 & 7 & 1.0 \\
\hline Total & 32 & & 86 & & 131 & & 196 & & 282 & & 727 & \\
\hline
\end{tabular}

Note: The test for trend for quality-of-care measures for antibiotic prescription for children with bacterial tonsillitis resulted in $P<0.0001$ at both sites.

2- to 12-month age groups. This increase occurred at the same time that prescriptions for other antibiotics declined. The number of encounters in which no antibiotic was prescribed remained low for all years.

For tonsillitis in children aged 1-4 years, the percentage of encounters in which amoxicillin was prescribed was higher in the initial years of implementation (2005) than for pneumonia-55.0\% at site 1 and $84.4 \%$ at site 2. By 2006, adherence to treatment guidelines reached $84.9 \%$ or higher at both sites. The other antibiotics prescribed were trimethroprim sulfa, penicillin, erythromycin, cefadroxil, and gentamicin. Trimethroprim sulfa was the most commonly prescribed antibiotic after amoxicillin. The test for trend for adherence to treatment guidelines for pneumonia and tonsillitis is significant $(P<0.0001)$ for both sites.

Table 7 presents the clinical encounters of people living within the catchment area in each of the two implementation sites for 2005-2009. Overall, Bocacosta, Sololá, has a higher number of clinical encounters for all years than San Juan Ostuncalco. The test for trend is significant $(P<0.0001)$ at both sites for reduction in the percentage of families with no clinic visits each year. The mean number of clinic visits per family member increases in Bocacosta, Sololá, from 0.89 to 1.40 and in San Juan Ostuncalco from 0.32 to 1.08 .

According to a study by Monzón and Valladares conducted to estimate the cost of the Modelo Incluyente de Salud based on 2007 implementation costs, the per capita cost was \$19.47 in Bocacosta, Sololá, and \$27.24 in San Juan Ostuncalco (23). Recent projections have been based on existing infrastructure and health personnel, resulting in lower per capita cost estimates.

\section{DISCUSSION}

Overall the experience of implementing the Modelo Incluyente de Salud has demonstrated positive results with improvement over time and coverage levels for key indicators that are higher than the national average. The postnatal coverage of nearly $100.0 \%$ at both sites contrasts with the national average of $25.6 \%$. Vaccination coverage for children 12-23 months old reached $96.1 \%$ at site 1 and $92.7 \%$ at site 2 compared with the national average of $71.2 \%$ (9).

Comparative results for utilization nationally are not available because the Ministry of Health and its nongovernmental organization partners implementing Extensión de Cobertura do not track clinical service use with individual and family codes that allow for attribution to specific people. Similarly, comparative results for quality are not available because the Ministry of Health does not systematically track adherence to treatment guidelines, number of days after delivery, and postpartum visits. Adherence to national treatment guidelines increased significantly at both sites, with a marked increase between 2006 and 2007. This increase is likely due to implementation of systematic supervisory visits during clinical encounters, beginning in 2006.

Some differences between the two demonstration sites warrant discussion. The population is larger in Bocacosta, Sololá, than in San Juan Ostuncalco. Despite the fact that the same number of health care providers work at each of the

TABLE 7. Annual use of clinic services in Bocacosta, Sololá, and San Juan Ostuncalco, 2005-2009

\begin{tabular}{lccccc}
\hline & 2005 & 2006 & 2007 & 2008 & 2009 \\
\hline $\begin{array}{l}\text { Bocacosta, Sololá (site 1) } \\
\quad \text { Total number of families }\end{array}$ & 1456 & 1753 & 1783 & 1841 & 1829 \\
$\quad \begin{array}{l}\text { Average annual clinic visits per family/ } \\
\text { number of family members (SD) }\end{array}$ & & & & & \\
$\quad$ Families that made no clinic visits during the year (\%) & $0.89(1.18)$ & $0.99(1.15)$ & $0.91(0.99)$ & $1.08(0.99)$ & $1.40(1.17)$ \\
San Juan Ostuncalco (site 2) & 31.4 & 20.0 & 17.7 & 7.9 & 7.5 \\
$\quad \begin{array}{l}\text { Total number of families } \\
\text { Average annual clinic visits per family/ } \\
\quad \text { number of family members (SD) }\end{array}$ & 1353 & 1320 & 1327 & 1335 & 1352 \\
$\quad$ Families that made no clinic visits during the year (\%) & $0.32(0.58)$ & $0.75(0.93)$ & $0.79(0.90)$ & $1.03(1.12)$ & $1.08(1.09)$ \\
\hline
\end{tabular}

Note: SD: standard deviation. 
two sites, the service coverage and utilization rates tend to be higher in Bocacosta, Sololá. San Juan Ostuncalco had higher staff turnover at all levels. Another factor that may have influenced the relative success of Bocacosta is the confidence the community had in the institution that initially led the implementation.

The findings of the process evaluation of the Modelo Incluyente de Salud are consistent with the conceptual model. The mediating variables (coverage, quality of care, and utilization) all increase significantly during the 5-year implementation period. This finding offers a strong possibility that the model may benefit health outcomes as well as process measures.

The cost of the Modelo Incluyente de Salud is elevated compared with the current standard of rural primary care, which is about $\$ 8$ per capita (24). However, the cost is within the recommendations of the World Health Organization's Commission of Macroeconomics and Health, which proposed in 2001 that low-income countries invest a minimum of \$30-\$40 per person in order to cover essential interventions (25). It is important to recognize that the cost of this model has required an initial investment Alma-Ata. International Conference on Primary Health Care, Alma-Ata, USSR, 6-12 September 1978. Geneva: WHO; 1978.

2. Pan American Health Organization, World Health Organization. Renewing primary health care in the Americas: a position paper of the Pan American Health Organization/ World Health Organization. Washington, DC: PAHO; 2007.

3. Gofin J, Gofin R. Atención primaria orientada a la comunidad: un modelo de salud pública en la atención primaria. Rev Panam Salud Publica. 2007;21(2/3):177-85.

4. Kruk ME, Porignon D, Rockers PC, Van Lerberghe $\mathrm{W}$. The contribution of primary care to health and health systems in low- and middle-income countries: a critical review of major primary care initiatives. Soc Sci Med. 2010;70:904-11.

5. Perry HB, Shanklin DS, Schroeder DG. Impact of a community-based comprehensive primary healthcare programme on infant and child mortality in Bolivia. J Health Popul Nutr. 2003;21(4):383-95.

6. Perry $\mathrm{H}$, Robinson $\mathrm{N}$, Chavez D, Taja O, Hilari C, Shanklin D, et al. The census-based, impact-oriented approach: its effectiveness in promoting child health in Bolivia. Health Policy Plan. 1998;13(2):140-51.

7. Organización Panamericana de la Salud. Sistemas de salud basados en la atención primaria de salud: estrategias para el desarrollo in meetings and training in implementing clinical guidelines, preparing technical documents, a high level of monitoring and supervision, and other start-up costs (26). Given that Guatemala is classified as a lower- to middle-income country with a per capita gross national income ranging from $\$ 976$ to $\$ 3855$, the per capita government investment in health could be expected to be even greater than what the Modelo Incluyente de Salud costs (27). This new model has provided services at no cost to the population in its catchment area, while the trend in Guatemala from 2003 to 2007 is that the population has paid an increasing proportion of health care costs out of pocket (28). At the end of 2010, the Guatemalan Ministry of Health officially decided to financially sustain the Modelo Incluyente de Salud in the two original pilot sites and to extend it to at least three additional sites in the country.

There are a number of limitations in this analysis. Quality of care was defined as the correct treatment of pneumonia or bacterial tonsillitis in children; this measure does not account for differential diagnosis. A more comprehensive analysis of quality would also include

\section{REFERENCES}

de los equipos de APS. Washington, DC: OPS; 2008.

8. Barrett B. Integrated local health systems in Central America. Soc Sci Med. 1996;43(1): 71-82.

9. Ministerio de Salud Pública y Asistencia Social, Instituto Nacional de Estadística, Universidad del Valle de Guatemala, Agencia de los Estados Unidos para el Desarrollo Internacional, Agencia Sueca de Cooperación para el Desarollo Internacional, Centros para el Control y Prevención de Enfermedades, et al. Informe final: V Encuesta Nacional de Salud Materno Infantil: 2008-2009. Guatemala: Ministry of Health and Social Welfare of Guatemala; November 2009.

10. Ministry of Health and Social Welfare of Guatemala. The Guatemalan experience of the strategic alliance between the public sector and NGOs to provide basic health care services. Guatemala: MSPAS; 1999.

11. World Health Organization. Guatemala: country cooperation strategy at a glance. Available from: http://www.who.int/coun tryfocus/cooperation_strategy/ccsbrief_ gtm_en.pdf Accessed 18 November 2010.

12. Instancia Nacional de Salud. Hacia un primer nivel de atención incluyente: bases y lineamientos. Guatemala: INS; 2002.

13. Consejo Municipal de Desarrollo de Santa Catarina Ixtahuacán, Sololá, Secretaría de Planificación y Programación de la Presidencia. Plan de desarrollo municipal Santa the study of diagnostic practices, which would require on-site observation. The analysis of utilization does not include an assessment of need, which will be important to consider in the future. Another limitation is that a one-to-one comparative analysis was not conducted for coverage comparisons at a national level; this will be the focus of a future study.

This article has described the Modelo Incluyente de Salud and presented changes in service coverage, quality of care, and utilization from 2005 to 2009. In addition, when possible, process evaluation results for the Modelo Incluyente de Salud are compared with national-level results. Given the results from this process evaluation, the Ministry of Health could be expected to increase the coverage of key health care services and offer on-demand clinical care to the population with a relatively small investment. Aspects of the inclusive nature of the project are important considerations for other countries in the region where indigenous populations or other minority or underserved populations have lower-than-average coverage measures compared with the population as a whole.
Catarina Ixtahuacán, Sololá. Guatemala: SEGEPLAN/DPT; 2010.

14. Consejo Municipal de Desarrollo de San Juan Ostuncalco, Quetzaltenango, Secretaría de Planificación y Programación de la Presidencia. Plan de desarrollo municipal San Juan Ostuncalco, Quetzaltenango. Guatemala: SEGEPLAN/DPT; 2010.

15. Hart, JT. Commentary: can health outputs of routine practice approach those of clinical trials? Int J Epidemiol. 2001;30:1263-7.

16. Hart JT, Thomas C, Gibbons B, Edwards C, Hart M, Jones J, et al. Twenty-five years of case finding and audit in a socially deprived community. Br Med J. 1991;302:1509-13.

17. Svitone EC, Garfield R, Vasconcelos MI, Craveiro VA. Primary health care lessons for the northeast of Brazil: the Agentes de Saude Program. Rev Panam Salud Publica. 2000; 7(5):293-301.

18. Vargas González, W. Atención primaria de salud en acción: su contexto histórico, naturalez y organización en Costa Rica. San José: Editorial Nacional de Salud y Seguridad Social: Caja Costarricense de Seguro Social; 2006.

19. Moliner RB, Soberats FS, Cañizares PF, Lorenzo A, Delgado HC. La dispensarización: una vía para la evaluación del proceso salud-enfermedad. Rev Cubana Med Gen Integr. 2001;17(2):109-20.

20. Andersen, R. A behavioral model of families' use of health services. Research Series 25 . 
Chicago: Center for Health Administration Studies, University of Chicago; 1968.

21. Banco de Guatemala. Available from: http:// www.banguate.gob.gt/cambio/historico Accessed 18 April 2011.

22. Instituto Nacional de Estadística. Encuesta Nacional de Condiciones de Vida (ENCOVI2006). Guatemala: INE; 2006.

23. Monzón I, Valladares R. Estudio de costos del Modelo Incluyente de Salud, informe final. Proyecto la Construcción Social del Futuro de la Salud. Guatemala: Programa de las Naciones Unidas para el Desarrollo; 2008.

24. Ministry of Health and Social Welfare of Guatemala. Por qué es prioritario fortalecer el presupuesto del Ministerio de Salud. Guatemala: Ministry of Health and Social Welfare; 2008.

25. World Health Organization. Macroeconomics and health: investing in health for economic development. Report of the Commission on Macroeconomics and Health. Geneva, WHO; 2001.

26. Medicus Mundi Navarra Guatemala. 2008. Del dicho al hecho ... L Los avances de un primer nivel de atención en salud incluyente. Guatemala: Medicus Mundi Navarra Guatemala; 2008

27. World Bank. Country classifications. Available from: http://data.worldbank.org/about/ country-classifications Accessed 20 May 2010.

28. World Health Organization. National health accounts 2003-2007. Available from: http:// www.who.int/nha/country/en/index.html Accessed 6 June 2010.

Manuscript received on 19 November 2010. Revised version accepted for publication on 2 June 2011.

RESUMEN Objetivo. Describir un modelo de atención primaria de salud diseñado específicamente para Guatemala que se ha ejecutado en dos sitios piloto desde 2004 y presentar los resultados de una evaluación de la utilización, la cobertura de servicios y la calidad de la atención entre 2005 y 2009.

Ejecución y avance de un modelo inclusivo de atención primaria de salud en Guatemala: cobertura, calidad y utilización

Métodos. Se evaluaron la cobertura, la utilización y la calidad mediante una base de datos automatizada que relaciona los datos obtenidos a partir de un censo con los registros clínicos, y su evolución se informó a lo largo del tiempo. Se compararon las medidas clave de cobertura de la salud maternoinfantil con las medidas obtenidas en el nivel nacional.

Resultados. La cobertura posnatal lograda por el Modelo Incluyente de Salud, de casi $100,0 \%$ en ambos sitios, contrasta con el promedio nacional de $25,6 \%$. La cobertura de vacunación de los niños de 12 a 23 meses de edad en dicho modelo alcanzó 95,6\% en el sitio 1 (Bocacosta, Sololá) y 92,7\% en el sitio 2 (San Juan Ostuncalco), en comparación con el promedio nacional de $71,2 \%$. El cumplimiento de las directrices nacionales de tratamiento aumentó significativamente en los dos sitios, con un aumento acentuado entre 2006 y 2007. La utilización aumentó significativamente en ambos sitios; al finalizar el período de 5 años no usaban los servicios solo 7,5\% de las familias en el sitio 1 y 11,2\% de las familias en el sitio 2 .

Conclusiones. Las medidas de cobertura, calidad de la atención y utilización aumentaron significativamente durante el período de 5 años durante el cual se ejecutó el modelo de prestación de servicios. Estos datos indican firmemente que el modelo puede mejorar tanto los resultados relacionados con la salud como las medidas de proceso. El Modelo Incluyente de Salud será mantenido económicamente por el Ministerio de Salud Pública y Asistencia Social y se extenderá, al menos, a tres sitios más. El modelo proporciona enseñanzas importantes para los programas de atención primaria de otros países.

Palabras clave Atención primaria de salud; evaluación de programas y proyectos de salud; evaluación de servicios de salud; Guatemala. 